\title{
New Repeat Polymorphism in the AKT1 Gene Predicts Striatal Dopamine D2/D3 Receptor Availability and Stimulant-Induced Dopamine Release in the Healthy Human Brain
}

\author{
Elena Shumay, ${ }^{1 *}{ }^{\dagger}$ CCorinde E. Wiers, ${ }^{1 *}$ Ehsan Shokri-Kojori, ${ }^{1}$ Sung Won Kim, ${ }^{1}$ Colin A. Hodgkinson, ${ }^{2}$ Hui Sun, ${ }^{2}$ \\ Dardo Tomasi, ${ }^{1}$ CChristopher T. Wong, ${ }^{1}$ CDaniel R. Weinberger, ${ }^{4}$ Gene-Jack Wang, ${ }^{1}$ Joanna S. Fowler, ${ }^{1,5}$ \\ and $\odot$ Nora D. Volkow ${ }^{1,3}$ \\ ${ }^{1}$ Laboratory of Neuroimaging, ${ }^{2}$ Laboratory of Neurogenetics, National Institute on Alcohol Abuse and Alcoholism, ${ }^{3}$ National Institute on Drug Abuse, \\ National Institutes of Health, Bethesda, Maryland 20892, ${ }^{4}$ Lieber Institute for Brain Development, Johns Hopkins Medical Campus, Baltimore, Maryland \\ 21205, and ${ }^{5}$ Brookhaven National Laboratory, Upton, New York 11973
}

The role of the protein kinase Akt1 in dopamine neurotransmission is well recognized and has been implicated in schizophrenia and psychosis. However, the extent to which variants in the $A K T 1$ gene influence dopamine neurotransmission is not well understood. Here we investigated the effect of a newly characterized variant number tandem repeat (VNTR) polymorphism in AKT1 [major alleles: L- (eight repeats) and $\mathrm{H}$ - (nine repeats)] on striatal dopamine D2/D3 receptor (DRD2) availability and on dopamine release in healthy volunteers. We used PET and $\left[{ }^{11} \mathrm{C}\right]$ raclopride to assess baseline DRD2 availability in 91 participants. In 54 of these participants, we also measured intravenous methylphenidate-induced dopamine release to measure dopamine release. Dopamine release was quantified as the difference in specific binding of $\left[{ }^{11} \mathrm{C}\right]$ raclopride (nondisplaceable binding potential) between baseline values and values following methylphenidate injection. There was an effect of $A K T 1$ genotype on DRD2 availability at baseline for the caudate $\left(F_{(2,90)}=8.2, p=0.001\right)$ and putamen $\left(F_{(2,90)}=6.6, p=0.002\right)$, but not the ventral striatum $(p=0.3)$. For the caudate and putamen, LL showed higher DRD2 availability than HH; HL were in between. There was also a significant effect of AKT1 genotype on dopamine increases in the ventral striatum $\left(F_{(2,53)}=5.3, p=0.009\right)$, with increases being stronger in $\mathrm{HH}>\mathrm{HL}>\mathrm{LL}$. However, no dopamine increases were observed in the caudate $(p=0.1)$ or putamen $(p=0.8)$ following methylphenidate injection. Our results provide evidence that the AKT1 gene modulates both striatal DRD2 availability and dopamine release in the human brain, which could account for its association with schizophrenia and psychosis. The clinical relevance of the newly characterized AKT1 VNTR merits investigation.

Key words: AKT1; dopamine; dopamine receptor; methylphenidate; PET

Significance Statement

The AKT1 gene has been implicated in schizophrenia and psychosis. This association is likely to reflect modulation of dopamine signaling by Akt1 kinase since striatal dopamine hyperstimulation is associated with psychosis and schizophrenia. Here, using PET with [ ${ }^{11} \mathrm{C}$ ]raclopride, we identified in the $A K T 1$ gene a new variable number tandem repeat (VNTR) marker associated with baseline striatal dopamine D2/D3 receptor availability and with methylphenidate-induced striatal dopamine increases in healthy volunteers. Our results confirm the involvement of the $A K T 1$ gene in modulating striatal dopamine signaling in the human brain. Future studies are needed to assess the association of this new VNTR AKT1 variant in schizophrenia and drug-induced psychoses.

\section{Introduction}

Variations in dopamine (DA) signaling have been implicated in neuropsychiatric conditions, such as schizophrenia (SZ) and substance use disorder (SUD), and in pharmacological responses to drugs. Genes modulating DA signaling in the brain remain

reagents/analytic tools; E.S., C.E.W., E.S.-K., S.W.K., D.T., C.T.W., and N.D.V. analyzed data; E.S., C.E.W., E.S.-K., S.W.K., C.A.H., D.T., D.R.W., G.-J.W., J.S.F., and N.D.V. wrote the paper.

PET studies were performed at Brookhaven National Laboratory with infrastructure support from the Department of Energy and the National Institutes of Health Intramural Program (Y1AA3009). We thank 
mostly undetermined (Wong et al., 2000; Gluskin and Mickey, 2016) and few studies have investigated in particular the role of genes involved in downstream DA signaling, though its relevance is evident by findings documenting associations between DISC1, NRG1, and AKT1 with SZ (Jönsson et al., 1999; Hall et al., 2004; Gluskin and Mickey, 2016). Furthermore, AKT1 polymorphisms have been linked to risk for drug-induced psychosis (Di Forti et al., 2012; Morgan et al., 2016).

The involvement of the AKT1 gene in schizophrenia and psychosis may be mediated by the role of Akt1 kinase in DA receptor signaling through the noncanonical pathway that results in DA receptor internalization and desensitization (Li et al., 2016). Agonist binding to striatal dopamine $\mathrm{D} 2 / \mathrm{D} 3$ receptor (DRD2) leads to formation of a multimolecular scaffold comprising $\beta$-arrestin 2 and several kinases, including Akt1, protein phosphatase $2 \mathrm{~A}$ (PP2A), and glycogen synthase kinase-3 (GSK3; for review, see Gainetdinov et al., 2004). Akt1 kinase is a critical downstream effector of this signaling cascade whose activity is counterregulated by extracellular DA levels such that DA increases reduce its activity (Zheng et al., 2013), whereas DA depletion elevates it (Bychkov et al., 2007; Ohi et al., 2013). DA binding to DRD2 directly induces Akt1 phosphorylation (Jönsson et al., 1999) and is essential for the behavioral manifestation of stimulants and antipsychotics drugs (Jönsson et al., 1999; Beaulieu et al., 2007; Pan et al., 2011). Moreover, cocaine self-administration in rats increased the total and phosphorylated levels of Akt1 in the nucleus accumbens (Hirvonen et al., 2009). Lower Akt1 appears to enhance DRD2 stimulation (Arguello and Gogos, 2008) and $A K T 1^{-1-}$ mice show enhanced DA neurotransmission (Jönsson et al., 1999) and poorer working-memory performance when challenged with amphetamine (Emamian et al., 2004).

A few studies have investigated the role that variations in the $A K T 1$ gene have on brain function. In SZ, AKT1 single nucleotide polymorphism (SNP) rs2494732 was associated with attention deficits and brain morphology (Ohi et al., 2013) and AKT1 SNP rs1130233 was associated with cingulate response during attentional processing (Blasi et al., 2011). In healthy volunteers, $A K T 1$ SNP rs1130233 showed involvement in cortical and striatal brain volumes (Tan et al., 2008, 2012b) and in functional responses during working memory (Tan et al., 2012a). To our knowledge no study to date has investigated the association between AKT1 polymorphisms and striatal density of DRD2 or striatal DA release in humans.

Here, we report on a new variant number tandem repeat (VNTR) polymorphism in the human AKT1 gene that was associated with striatal DA function. Repeats are potentially good predictors of brain function (Weber and Wong, 1993; Hirvonen et al., 2004) since they represent fast evolving sequences in the human genome (Brinkmann et al., 1998), exhibit elevated mutation rates (Gulcher, 2012), and alter the number of CpG (cytosinephosphate-guanine) sites amenable to epigenetic regulation. Here we hypothesized that the AKT1 VNTR would modulate both (1) baseline striatal DRD2 availability and (2) striatal DA release. To test this hypothesis, we used PET with $\left[{ }^{11} \mathrm{C}\right]$ raclopride

\footnotetext{
Karen Apelskog-Torres for study protocol preparation, and Barbara Hubbard, Maynard Jane and Pauline Carter for participant care. We also thank our study participants.

${ }^{*}$ E.S. and C.E.W. contributed equally to this work.

The authors declare no competing financial interests.

${ }^{\dagger}$ Deceased, 0ct. 5, 2015.

Correspondence should be addressed to Nora D. Volkow, Laboratory of Neuroimaging, NIH/NIAAA, Center Drive 31, Building 10, Room B2L124, Bethesda, MD 20892. E-mail: nvolkow@nida.nih.gov.

DOI:10.1523/JNEUROSCI.3155-16.2017

Copyright $\odot 2017$ the authors $\quad 0270-6474 / 17 / 374983-10 \$ 15.00 / 0$
}

to measure DRD2 availability at baseline and we measured DA release by assessing the changes in the specific binding of $\left[{ }^{11} \mathrm{C}\right] \mathrm{ra}-$ clopride elicited by the stimulant drug methylphenidate (MP; Volkow et al., 1994).

\section{Materials and Methods}

Computational analyses. In silico analysis of AKT1 included assessing transcript variants, promoter genetic elements, interspecies genetic conservation, and reported sequence variations and patterns of alternative splicing, for which we used GenBank (http://www.ncbi.nlm.nih.gov/ genbank, RRID:SCR_002760), the University of California Santa Cruz (UCSC) Genome Browser (http://genome.ucsc.edu, RRID:SCR_005780), and the Evolutionary Conserved Regions Browser (http://ecrbrowser.dcode. org, RRID:SCR_001052). Reported variations in the AKT1 sequence were retrieved from the 1000 Genome Catalog of Human Genetic Variation (http://browser.1000genomes.org/Homo_sapiens/Search/Results?site= ensembl\&q=AKT1, RRID:SCR_006828). Evidence-based data on structural variations (copy number variations) in $A K T 1$ were obtained with the Database of Genomic Variants (http:/dgv.tcag.ca/dgv/, RRID: SCR_007000; MacDonald et al., 2014). Estimates of repeats variability and their potential suitability as genetic markers were conducted using the Sequence-Based Estimation of Repeat Variability server (http://www. igs.cnrs-mrs.fr/SERV/; Legendre and Verstrepen, 2008). Guaninecytosine (GC) composition of the genetic sequences was assessed with the Genomics \%G C Content Calculator (http://www.sciencebuddies.org/ science-fair-projects/project_ideas/Genom_GC_Calculator.shtml).

Participants. For the baseline measures of DRD2 availability, we included 91 unrelated healthy individuals of mixed ancestry who had undergone a baseline PET scan with $\left[{ }^{11} \mathrm{C}\right]$ raclopride (Table 1$)$. Of these, $N=51$ (Table 2) also underwent a second PET $\left[{ }^{11} \mathrm{C}\right]$ raclopride scan after a challenge with MP $(0.5 \mathrm{mg} / \mathrm{kg}$, i.v. $)$, which was used to assess DA release (measured as the difference in specific binding of $\left[{ }^{11} \mathrm{C}\right]$ raclopride between the baseline and the MP scans). All participants agreed to participate in the imaging and genetic studies and provided written informed consent. Participants were excluded if they had a history of substance abuse or dependence (other than nicotine) or a history of psychiatric disorder (as per Diagnostic and Statistical Manual of Mental Disorders, fourth edition; RRID:SCR_003682), neurological disease, medical conditions that may alter cerebral function (i.e., cardiovascular, endocrinological, oncological, or autoimmune diseases), current use of prescribed or over-the-counter medications, and/or head trauma with loss of consciousness of $>30 \mathrm{~min}$. The Institutional Review Board committee of Stony Brook University approved the studies.

Collection of DNA samples and genotyping. DNA was extracted from venous blood using the Qiagen kit according to manufacturer's instructions (RRID:SCR_008539).

The VNTR region was amplified by PCR using the following primers: forward, ctccagcttccagagca; reverse, ctgggctggcaagcaa. The size of the PCR products was established by the QIAxcel system of multicapillary electrophoresis. In the reference genome (UCSC Genome Browser, assembly hg38, RRID:SCR_005780) this simple tandem repeat is represented by a 432 bp sequence. In our population sample we identified primary sequences containing 9- and 7- copies of consensus increments. Herein, we referred to the respective major alleles as L- (eight repeats) and $\mathrm{H}$ - (nine repeats). The seven-repeat allele was "rare," appearing in only $1.5 \%$ of the samples. Genotype accuracy was confirmed with an independent PCR analysis of the same samples in multiples ( 50\% of each sample was tested in duplicates and $\sim 10 \%$ in triplicates). All tested samples were successfully genotyped and the PCR results were 100\% reproducible. Based on the PCR results, we ascribed the individual genotypes. Allele and genotype frequencies were analyzed with software from the Online Encyclopedia for Genetic Epidemiology Studies (http://www. oege.org/software/hardy-weinberg.html; RRID:SCR_001825). We implemented a three-genotype classification, where the carriers of each genotype formed a separate group.

To explore associations between the novel AKT1 VNTR and the commonly reported AKT1 polymorphism rs2494732, we genotyped rs 2494732 using off-the-shelf Taqman assay for rs2494732 available as a kit 
Table 1. Demographics of $N=91$ participants who were scanned with PET and $\left[{ }^{11} \mathrm{C}\right]$ raclopride DRD2 at baseline; separated for $A K T 1$ genotype

\begin{tabular}{|c|c|c|c|c|c|c|c|c|}
\hline & \multicolumn{2}{|c|}{$\begin{array}{l}\mathrm{HH} n=32 \\
\text { (8 female; } 25 \%)\end{array}$} & \multicolumn{2}{|c|}{$\begin{array}{l}\mathrm{HL} n=43 \\
\text { (7 female; 16\%) }\end{array}$} & \multicolumn{2}{|c|}{$\begin{array}{l}\mathrm{LL} n=16 \\
\text { (0 female; } 0 \%)\end{array}$} & \multirow{2}{*}{$\begin{array}{l}\chi^{2}=4.85 \\
F_{(2,90)}\end{array}$} & \multirow{2}{*}{$\begin{array}{l}p=0.089 \\
P \text { value }\end{array}$} \\
\hline & Mean & SD & Mean & SD & Mean & SD & & \\
\hline \multicolumn{9}{|l|}{ Demographics } \\
\hline Age (years) & 33.7 & 8.1 & 34.8 & 8.5 & 34.0 & 8.5 & 0.15 & 0.86 \\
\hline Education (years) & 14.5 & 2.5 & 14.0 & 2.0 & 13.9 & 2.1 & 0.66 & 0.52 \\
\hline Body mass index & 25.5 & 2.7 & 26.0 & 3.0 & 24.5 & 3.0 & 1.41 & 0.25 \\
\hline \multirow[t]{2}{*}{ Beck depression inventory } & 3.0 & 4.2 & 3.8 & 6.2 & 3.1 & 3.6 & 0.22 & 0.80 \\
\hline & $n$ & $\%$ & $n$ & $\%$ & $n$ & $\%$ & $\chi^{2}$ & $P$ value \\
\hline \multicolumn{9}{|l|}{ Ethnicity } \\
\hline African American & 16 & 50 & 16 & 37 & 4 & 25 & 12.6 & 0.049 \\
\hline Caucasian & 6 & 19 & 18 & 42 & 10 & 63 & & \\
\hline Hispanic & 5 & 16 & 2 & 5 & 2 & 12 & & \\
\hline \multirow[t]{2}{*}{ More than one } & 5 & 16 & 7 & 16 & 0 & 0 & & \\
\hline & Mean & SD & Mean & SD & Mean & SD & $F_{(2,90)}$ & $P$ value* \\
\hline \multicolumn{9}{|c|}{ Baseline $\mathrm{D} 2 / 3$ receptor availability $\left(\mathrm{BP}_{\mathrm{ND}}\right)$} \\
\hline Caudate & 2.4 & 0.43 & 2.6 & 0.58 & 2.9 & 0.43 & 4.78 & 0.001 \\
\hline Putamen & 3.1 & 0.51 & 3.3 & 0.65 & 3.5 & 0.49 & 3.28 & 0.002 \\
\hline VS & 2.9 & 0.43 & 2.9 & 0.50 & 3.1 & 0.45 & 0.67 & 0.57 \\
\hline
\end{tabular}

*Multivariate test corrected for age, gender, and ethnicity.

Table 2. Demographics of $N=54$ participants who underwent $\left[{ }^{11} \mathrm{C}\right]$ raclopride DRD2 baseline and intravenous MP scans; separated for $A K T 1$ genotype

\begin{tabular}{|c|c|c|c|c|c|c|c|c|}
\hline & \multicolumn{2}{|c|}{$\begin{array}{l}\mathrm{HH} n=19 \\
\text { (6 female; } 31.6 \% \text { ) }\end{array}$} & \multicolumn{2}{|c|}{$\begin{array}{l}\mathrm{HL} n=27 \\
\text { (7 female; } 25.9 \% \text { ) }\end{array}$} & \multicolumn{2}{|c|}{$\begin{array}{l}\mathrm{LL} n=8 \\
\text { (0 female; } 0 \%)\end{array}$} & \multirow{2}{*}{$\begin{array}{l}\chi^{2}=3.17 \\
F_{2,53}\end{array}$} & \multirow{2}{*}{$\frac{p=0.21}{P \text { value }}$} \\
\hline & Mean & SD & Mean & SD & Mean & SD & & \\
\hline \multicolumn{9}{|l|}{ Demographics } \\
\hline Age (years) & 34.8 & 7.9 & 35.3 & 8.3 & 38.8 & 9.8 & 0.69 & 0.51 \\
\hline Education (years) & 14.9 & 2.8 & 14.4 & 2.1 & 14.1 & 1.7 & 0.42 & 0.66 \\
\hline Body mass index & 25.3 & 2.3 & 26.4 & 2.6 & 24.4 & 3.4 & 2.13 & 0.13 \\
\hline \multirow[t]{2}{*}{ Beck depression inventory } & 2.6 & 3.6 & 4.4 & 7.1 & 3.1 & 4.2 & 0.55 & 0.58 \\
\hline & $n$ & $\%$ & $n$ & $\%$ & $n$ & $\%$ & $x^{2}$ & $P$ value \\
\hline \multicolumn{9}{|l|}{ Ethnicity } \\
\hline African American & 11 & 58 & 11 & 41 & 2 & 25 & 17.36 & 0.008 \\
\hline Caucasian & 1 & 5 & 9 & 33 & 6 & 75 & & \\
\hline Hispanic & 4 & 21 & 1 & 4 & 0 & 0 & & \\
\hline \multirow[t]{2}{*}{ More than one } & 3 & 16 & 6 & 22 & 0 & 0 & & \\
\hline & Mean & SD & Mean & SD & Mean & SD & $F_{(2,53)}$ & $P$ value ${ }^{*}$ \\
\hline \multicolumn{9}{|l|}{ DA release $\left(\mathrm{BP}_{\mathrm{ND}}\right.$ placebo-MP) } \\
\hline Caudate & 0.55 & 0.56 & 0.36 & 0.33 & 0.22 & 0.16 & 2.14 & 0.13 \\
\hline Putamen & 0.93 & 0.66 & 0.74 & 0.42 & 0.49 & 0.45 & 1.39 & 0.26 \\
\hline VS & 0.76 & 0.59 & 0.35 & 0.48 & 0.03 & 0.72 & 5.25 & 0.009 \\
\hline
\end{tabular}

*Multivariate test corrected for age, gender, and ethnicity.

(Thermo Fisher Scientific). We explored its linkage disequilibrium (LD) with the VNTR in our sample using Haploview (Barrett et al., 2005; RRID:SCR_003076).

PET scans. $\left[{ }^{11} \mathrm{C}\right]$ raclopride scans used in this study have been acquired and reported previously for different study purposes (Volkow et al., 2012b, 2014a,b). All PET scans were performed on a Siemens HR + scanner following procedures previously reported (Volkow et al., 2014b).

Baseline PET images with $\left[{ }^{11} \mathrm{C}\right]$ raclopride $(N=91)$ were obtained to measure striatal DRD2 availability. For $N=54$ of these participants, a second $\left[{ }^{11} \mathrm{C}\right]$ raclopride was obtained after a challenge with MP, which was used to quantify DA release. The estimates of DA release were calculated as the difference in nondisplaceable binding potential $\left(\mathrm{BP}_{\mathrm{ND}}\right)$ of [11C]raclopride between baseline and MP (Volkow et al., 1994, 2012b). Details on the PET scanning protocol and procedure for MP administration have been previously described (Volkow et al., 2014b). In short, emission scans were started immediately after injection of $4-8 \mathrm{mCi}$ (specific activity $0.5-1.5 \mathrm{Ci} / \mu \mathrm{M}$ at end of bombardment). Twenty dynamic emission scans were obtained from time of injection up to $60 \mathrm{~min}$ after and arterial sampling was used to quantify total carbon-11 and unchanged $\left[{ }^{11} \mathrm{C}\right]$ raclopride in plasma.

To ensure minimal misplacements upon repositioning, we used a custom-made personalized head holder positioned by a set of two orthogonal lasers aligned to the canthomeatal $(\mathrm{CM})$ plane and the medial sagittal plane for each individual. Motion was minimized by means of the customized head holder, which impeded rotation and lateral movements and by using strap bands to minimize displacements in the $z$ planes. Additionally, the dynamic emission scan images were evaluated before analyses to ensure that any motion artifacts or misplacements that would confound the measures were not included in the analyses.

Region of interest analyses. We calculated regional $\mathrm{BP}_{\mathrm{ND}}$ values for hand-drawn caudate, putamen, and ventral striatum (VS) regions of interest (ROIs) using a procedure previously described (Wang et al., 1999). In short, bilateral caudate, putamen, VS, and cerebellar ROIs were drawn directly in an averaged emission image (summation of images obtained between 10 and $60 \mathrm{~min}$ ). Striatal ROIs for the caudate, putamen, and VS were obtained from three sequential axial planes where the ROIs were 


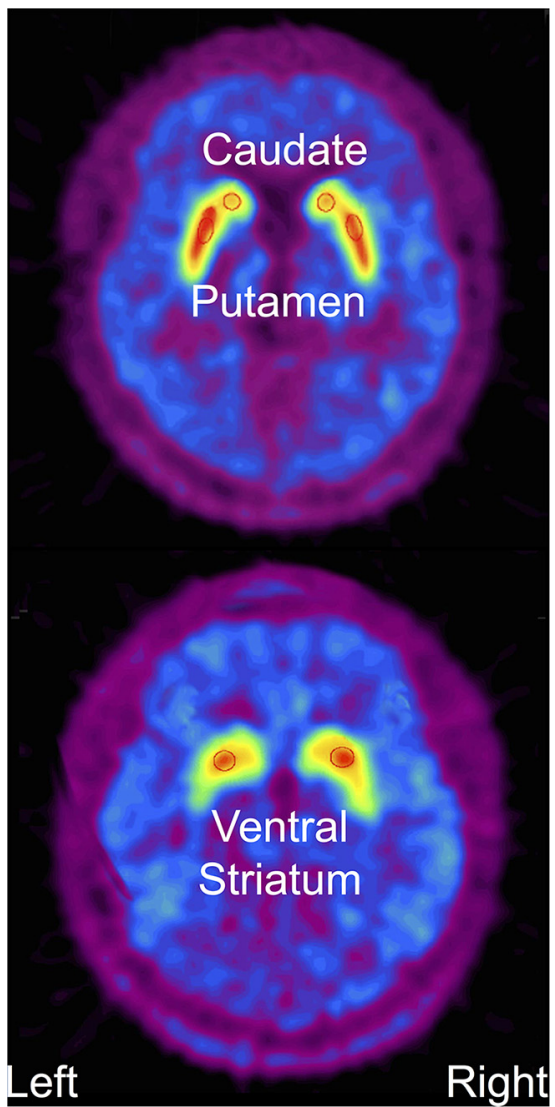

Figure 1. Striatal ROls: bilateral caudate, putamen, and VS for PET analyses. ROls had the same size and shape for every subject. The ratio of the DV in striatal regions was compared to that in the cerebellum to obtain the $\mathrm{BP}_{\mathrm{ND}}$, which was used to quantify $\mathrm{DRD} 2$ availability.

most visible, and had the same size and shape across subjects: 2.2, 2.2, and $0.8 \mathrm{~mm}^{3}$ respectively (Fig. 1). For the cerebellum, we averaged the values obtained from circular ROIs in the left and right cerebellum $\left(16 \mathrm{~mm}^{3}\right)$ in three contiguous axial planes positioned within 1.0 and $1.7 \mathrm{~cm}$ above the $\mathrm{CM}$ line. ROI values were computed using the weighted average for the left and right regions from the different slices where the regions were obtained. Time-activity curves in the striatum and cerebellum along with the concentration of the nonmetabolized tracer in plasma were used to obtain the distribution volume (DV) using a reference tissue model (Logan et al., 1990, 1996). The ratio for DV in the striatum to that in the cerebellum corresponds to $\mathrm{BP}_{\mathrm{ND}}$ and was used to quantify DRD2 availability (Logan et al., 1990).

Statistical analyses on the striatal ROIs were performed with SPSS version 20 (IBM, RRID:SCR_002865). For the baseline DRD2 measures $(N=91)$, we performed multivariate analyses with $A K T 1$ as the betweengroup variable and DRD2 $\left(\mathrm{BP}_{\mathrm{ND}}\right)$ in the caudate, putamen, and VS as dependent variables. For MP-induced DA release $(N=54)$, we calculated multivariate analyses using Roy's largest root with $A K T 1$ as between-group variable and (placebo-MP) DRD2 in caudate, putamen, and VS as dependent variables. Post hoc univariate tests (for each striatal region) and post hoc Bonferroni's contrasts (for each genotype per striatal region) were performed to investigate directions of effects. Effect sizes are reported as partial $\eta$-squared $\left(\eta^{2}\right)$. Significance threshold was set at $p<$ 0.05 . Age, gender, and ethnicity were added as covariates. We repeated these analyses for AKT1 SNP rs2494732, to compare results with the novel $A K T 1$ VNTR.

Voxelwise analyses. We further analyzed the images on a pixel-by-pixel basis with Statistical Parametric Mapping (SPM8; Wellcome Trust Centre for Neuroimaging, London, UK, RRID:SCR_007037). For this purpose, we normalized the activity in each voxel (average activity, $10-60 \mathrm{~min}$ ) to that in the cerebellum. We used multiple-regression analyses in SPM8 to assess the effects of AKT1 genotype on (1) baseline DRD2 availability and (2) MP-induced DA release as computed by the difference images of placebo-MP. Age, gender, and ethnicity were included as covariates. We restricted the SPM analyses to a striatal mask ( 6228 voxels with $2 \mathrm{~mm}$ isotropic resolution) that covered the caudate, putamen, globus pallidus, and VS since the striatum is where our $\left[{ }^{11} \mathrm{C}\right]$ raclopride measures have sufficient signal-to-noise ratio to measure $\mathrm{BP}_{\mathrm{ND}}$ in the brain (Wang et al., 2012). Contrast analyses were corrected for familywise errors (FWEs) within the striatal mask with threshold-free cluster enhancement in the Oxford Centre for Functional MRI of the Brain Software Library (RRID:SCR_002823; Smith and Nichols, 2009; Winkler et al., 2014). Contrasts included the following: $\mathrm{HH}>\mathrm{HL}>\mathrm{LL}$; and the reverse direction: $\mathrm{HH}<\mathrm{HL}<\mathrm{LL}$. We also report exploratory findings at a liberal threshold of $p<0.05$ uncorrected $k>50$.

\section{Results}

\section{Identification and characterization of a new VNTR} polymorphism in the $A K T 1$ gene

In the reference genome (assembly hg38), the $A K T 1$ gene maps to the negative DNA strand of chromosome 14 (14q32.32; chr14: 104,769,350-104,795,743). Along with multiple SNPs (Fig. 2, Common SNPs), AKT1 encompasses several regions of simple repeats (Fig. 2, Simple Tandem Repeats).

We identified four AKT1 tandem repeats that exhibited propensity to instability and subsequently tested them in a population sample. One of the analyzed regions was polymorphic. This VNTR resides in intron3, immediately downstream of exon3 (chr14:104779602-104779962), where it is represented by $8.9 \mathrm{im}-$ perfect copies (match percentage, $80 \%$ ) of 42 nucleotide periods positioned in tandem.

\section{AKT1 VNTR alleles and genotype frequencies}

For all $N=91$ participants, the high-VNTR and low-VNTR alleles occurred with similar frequencies (59 and 41\%, respectively). Most individuals were heterozygotes (HL, $n=43 ; 47 \%$ ); followed by homozygous for the "high" allele ( $\mathrm{HH}, n=32 ; 35 \%)$, with the lowest frequency being the homozygous for the "low" allele (LL, $n=16 ; 18 \%$ ). The genotype frequencies did not deviate from Hardy-Weinberg equilibrium $\left(\chi^{2}=0.06, p=0.6\right)$. The genotype groups were similar with regards to age $\left(F_{(2,90)}=0.15\right.$, $p=0.9)$ and gender $\left(\chi^{2}=4.85, p=0.09\right)$, but differed in ethnicity $\left(F_{(2,90)}=12.6, p=0.049\right.$; Table 1$)$.

In the sample of $N=54$ individuals who underwent both placebo and MP scans, the frequencies of the $A K T 1$ VNTR alleles $(n=19 \mathrm{HH} ; n=27 \mathrm{HL} ; n=8 \mathrm{LL})$ were also in Hardy-Weinberg equilibrium $\left(\chi^{2}=0.1, p=0.6\right)$. There were also no group differences in age or gender, but they differed in ethnicity $\left(F_{(2,53)}=\right.$ 17.4, $p=0.008$; Table 2).

\section{Association of the AKT1 VNTR with striatal DRD2 availability}

For baseline measures, there were no outliers that exceeded 3 SDs for any striatal region. The multivariate ANOVA showed a significant effect of $A K T 1$ genotype on baseline striatal DRD2 availability $\left(\Theta=0.20, F_{(3,84)}=5.47, p=0.002, \eta^{2}=0.16\right)$. Effects were significant for the caudate $\left(F_{(2,90)}=8.2, p=0.001, \eta^{2}=0.16\right)$ and putamen $\left(F_{(2,90)}=6.6, p=0.002, \eta^{2}=0.13\right)$, but not for the VS $\left(F_{(2,90)}=0.5, p=0.6\right)$; all corrected for age, gender, and ethnicity (Fig. 3A). Bonferroni's post hoc tests showed that DRD2 availability in the caudate was higher in LL than $\mathrm{HH}(p=0.01)$, but there were no statistically significant differences between LL and HL $(p=0.1)$, or between HL and HH $(p=0.6)$. For the putamen, DRD2 availability was also higher in LL compared with $\mathrm{HH}(p=0.04)$, but did not differ between HL and LL $(p=0.3)$ or between HL and $\mathrm{HH}(p=0.6)$. 


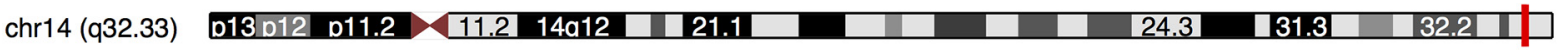

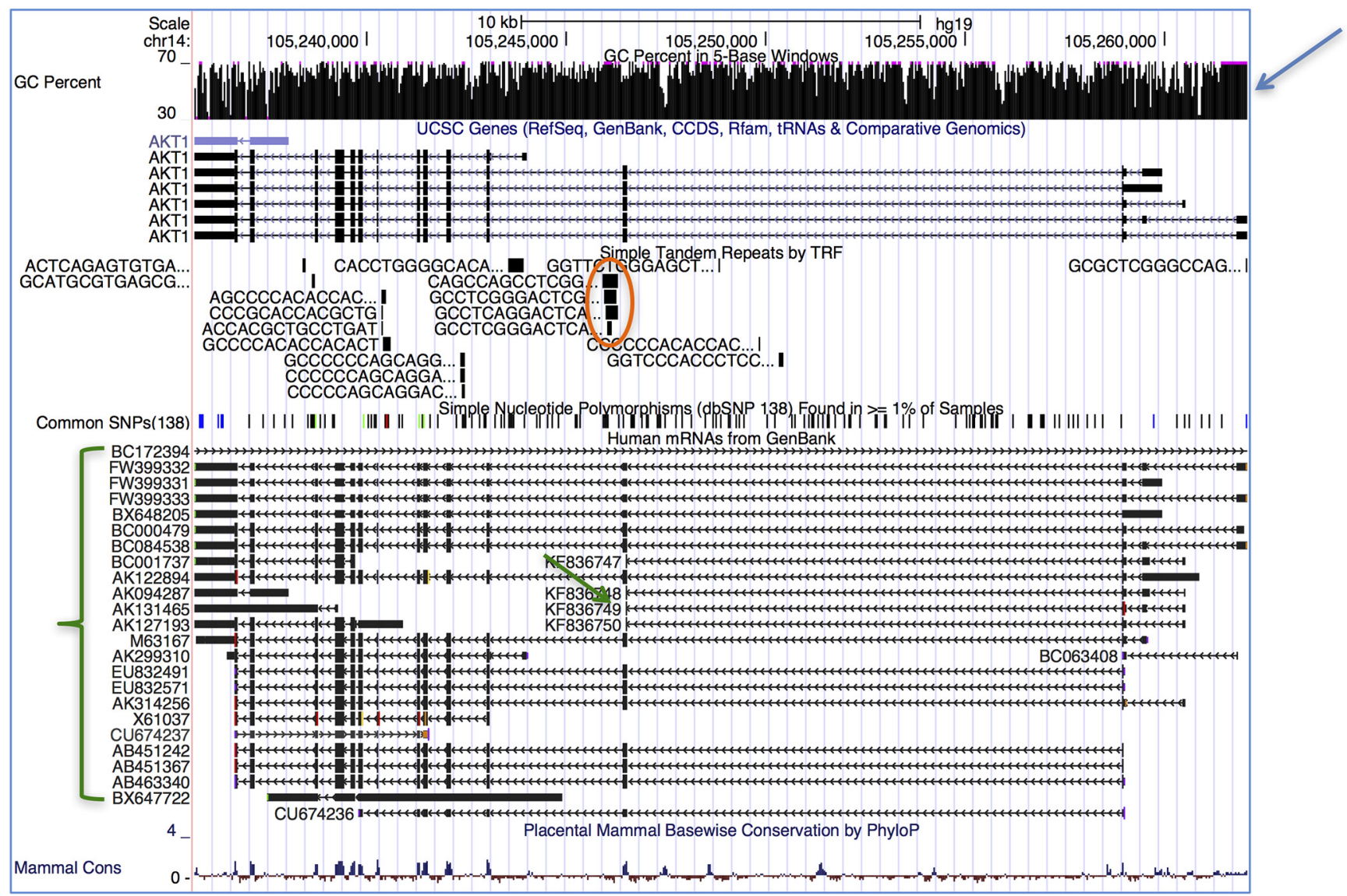

Figure 2. Location and genomic features of the human AKT1 gene. The chromosomal position of the AKT1 gene indicated with a red bar (chromosomal ideogram). A snapshot of the AKT1 locus (USCS Genome Browser, hg19) illustrates its principal genomic characteristics, including high (pG density (blue arrow indicates a track of GC percentage of the sequence with full display mode), numerous simple tandem repeats, and multiple alternatively spliced mRNAs (red bracket). Evolutionary conservation track at the bottom illustrates low sequence conservation across the mammalian species, which is constrained to coding elements.

DRD2 availability decreased with age in all three striatal ROIs (caudate $F_{(1,90)}=63.1, \eta^{2}=0.43$; putamen $F_{(1,90)}=67.3, \eta^{2}=$ 0.44 ; VS $F_{(1,90)}=38.8, \eta^{2}=0.31$; all $p$ 's $\left.<0.0001\right)$, which is consistent with previous findings (Volkow et al., 2000; Ishibashi et al., 2009; Kim et al., 2011). There were no effects of gender or ethnicity on DRD2 availability in any striatal region, and there were no region $\times$ group interactions.

SPM analysis for baseline DRD2 availability showed no significant clusters for either contrast at $p_{\mathrm{FWE}}<0.05$. Exploratory analyses at $p<0.05$ uncorrected $k>50$ showed an effect of AKT1 VNTR groups on baseline DRD2 availability $(\mathrm{HH}<\mathrm{HL}<\mathrm{LL})$ in bilateral striatum clusters [right peak (in MNI space): $[8,10,-8]$, $t=2.74, k=15, p=0.004$ (uncorrected); left peak: $[-12,10,2]$, $t=2.64, k=6, p=0.005$ uncorrected; covering caudate and anterior putamen]. There were no significant clusters for the reverse contrast of $\mathrm{HH}>\mathrm{HL}>\mathrm{LL}$.

\section{Association of the AKT1 VNTR with striatal DA} release (placebo-MP)

For DA release measures, there was one $>3$ SD outlier for the putamen and caudate, but not for VS. AKT1 genotype had an effect on striatal MP-induced DA release $\left(\Theta=0.25, F_{(3,47)}=\right.$ 3.84, $\left.p=0.015, \eta^{2}=0.20\right)$. Separate univariate ANOVAs showed that this effect was only significant for the VS $\left(F_{(2,53)}=5.3, p=\right.$ $\left.0.009, \eta^{2}=0.18\right)$, with Bonferroni's post hoc tests showing stronger DA release in $\mathrm{HH}>\mathrm{HL}(p=0.05)$ and in $\mathrm{HH}>\mathrm{LL}(p=$ 0.01 ; Fig. $3 B$ ). Thus, despite lower DRD2 in AKT1 genotype group $\mathrm{HH}<\mathrm{HL}<\mathrm{LL}, \mathrm{MP}$-induced DA release shows the opposite effect of an enhanced release in $A K T 1$ genotype groups $\mathrm{HH}>$ $\mathrm{HL}>\mathrm{LL}$. An exploratory analysis on raclopride $\mathrm{BP}_{\mathrm{ND}}$ during intravenous MP alone shows an even stronger effect of AKT1 genotype (caudate $F=10.57, p<0.0001$; putamen $F=10.71$, $p<0.0001$; VS $F=2.86, p=0.067$. There was a small nonsignificant age effect on DA release in putamen only $\left(F_{(2,53)}=4.5, p=\right.$ $\left.0.038, \eta^{2}=0.09\right)$, but no other effects of gender or ethnicity. There were also no region $\times$ group interactions.

There were no significant effects of AKT1 VNTR groups on striatal DA release at $p_{\mathrm{FWE}}<0.05$. However, exploratory analyses at $p<0.005$ uncorrected showed an effect of $A K T 1$ VNTR groups on striatal DA release $(\mathrm{HH}>\mathrm{HL}>\mathrm{LL})$ in the bilateral striatum (right peak: $[34,0,-2], t=3.41, k=64, p=0.001$ uncorrected; left peak: $[-16,12,-14], t=3.38, k=335, p=0.001$ uncorrected). Clusters covered the VS, caudate, and anterior putamen. There were no significant clusters for the reverse contrast $\mathrm{HH}<$ $\mathrm{HL}<\mathrm{LL}$. 

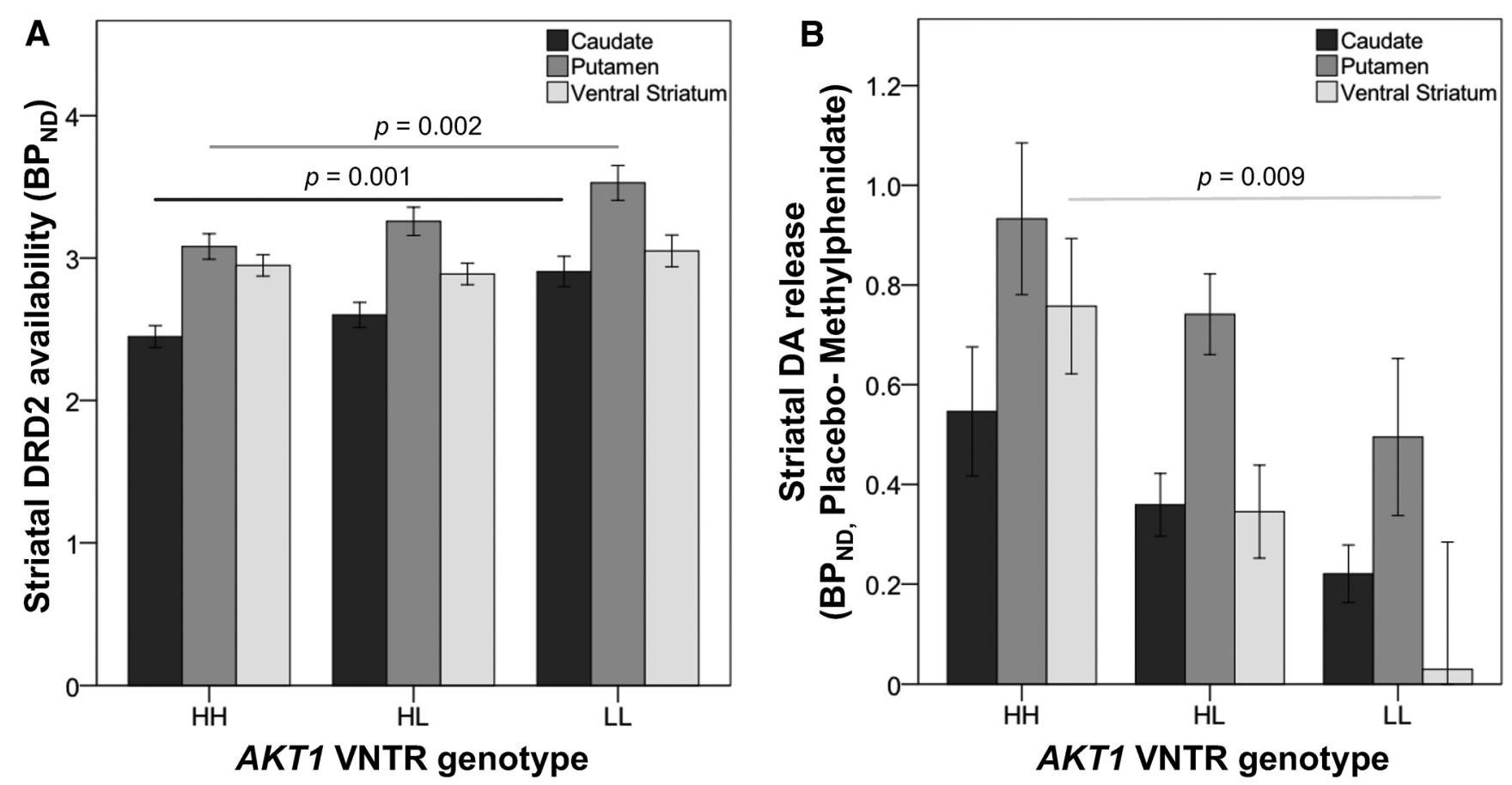

Figure 3. A, AKT1 VNTR genotype modulated baseline DRD2 availability in the caudate $(p=0.001)$ and putamen $(p=0.002)$, but not in the VS ( $p=0.6)$; corrected for age, gender, and ethnicity. Bonferroni's post hoc tests showed that DRD2 availability in the caudate was higher in LL than $\mathrm{HH}(p=0.01)$, but there were no differences between LL and $\mathrm{HL}(p=0.1)$ or between $\mathrm{HL}$ and HH $(p=0.6)$. B, AKT1 VNTR genotype modulated MP-induced DA release in the VS only $(p=0.009)$; corrected for age, gender, and ethnicity. Bonferroni's post hoc tests showed stronger DA release in $\mathrm{HH}>\mathrm{HL}(p=0.05)$ and in $\mathrm{HH}>\mathrm{LL}(p=0.01)$. Error bars depict SEM.

\section{Association between $A K T 1$ SNP rs2494732 and DRD2 and MP-induced DA release}

The AKT1 SNP rs2494732 has been associated with schizophrenia and with cannabis-induced psychoses (Di Forti et al., 2012; Morgan et al., 2016). Thus, we wanted to assess whether the new VNTR polymorphism was in linkage disequilibrium (LD) with rs2494732 and whether this SNP was associated with striatal DRD2 availability and DA release.

We found that there is low LD between the new AKT1 VNTR and AKT1 SNP rs2494732 $\left(d^{\prime}=0.524, r^{2}=0.167\right)$. AKT1 rs2494732 genotypes were in Hardy-Weinberg equilibrium (TT $=$ 22; $\left.\mathrm{CT}=53, \mathrm{CC}=17 ; \chi^{2}=2.89, p=0.52\right)$, and there were no differences in rs2494732 allelic distribution by gender $\left(\chi^{2}=1.19\right.$, $p=0.55)$, or ethnicity $\left(\chi^{2}=10.79, p=0.095\right)$. There was, however, a significant association between the allelic distribution of the AKT1 VNTR (HH/HL/LL) and rs2494732 (CC/CT/TT; $\left.\chi^{2}=20.98, p<0.001\right)$.

Analyses of the association between AKT1 SNP rs2494732 and DRD2 availability showed a trend-wise effect on baseline DRD2 in the putamen $\left(F_{(2,89)}=2.5, p=0.088, \eta^{2}=0.06\right.$; Fig. $\left.4 A\right)$. However, there were no significant effects in the caudate $\left(F_{(2,89)}=\right.$ $\left.2.1, p=0.12, \eta^{2}=0.05\right)$ or $\operatorname{VS}\left(F_{(2,89)}=0.26, p=0.77, \eta^{2}=\right.$ $0.006)$.

For DA release, there was an effect of rs2494732 in the putamen only $\left(F_{(2,53)}=5.4, p=0.008, \eta^{2}=0.17\right)$, with CC showing an enhanced DA response to MP than CT $(p=0.09)$ and TT ( $p=$ 0.008 ; Fig. $4 B)$. There were no significant effects in the caudate $\left(F_{(2,53)}=2.1, p=0.12, \eta^{2}=0.05\right.$, $)$ or VS $\left(F_{(2,53)}=0.26, p=0.77\right.$, $\left.\eta^{2}=0.006\right)$.

\section{Discussion}

Here we report the first evidence of an association between a newly identified AKT1 VNTR polymorphism and striatal baseline DRD2 availability and stimulant-induced striatal DA release.
Our analysis, which represents largest imaging genetics study on DA signaling in humans so far (Gluskin and Mickey, 2016), indicates that the novel AKT1 VNTR may serve as a predictive maker for striatal dopaminergic neurotransmission.

\section{Association between the AKT1 VNTR and striatal DRD2 availability}

We showed that an AKT1 VNTR located in intron3, immediately downstream of exon3, was associated with baseline striatal DRD2 availability in the healthy human brain. Specifically, LL had higher DRD2 availability in caudate and putamen ROIs than $\mathrm{HH}$, and heterozygotes (HL) were in between. We only showed a trend effect for AKT1 rs2494732 and DRD2 availability in the putamen. Exploratory SPM analyses also showed significant clusters for the contrast $\mathrm{HH}<\mathrm{HL}<\mathrm{LL}$ at $p<0.05$ uncorrected, covering the caudate and anterior putamen, but not for the reverse contrast of HH $>$ HL $>$ LL. These clusters, however, did not meet the cluster-correction criterion at $p_{\mathrm{FWE}}<0.05$. Changes in striatal DRD2 availability have been implicated in SUD (Volkow et al., 2012a; Hou et al., 2014) and SZ (Weinstein et al., 2016), with the latter disorder mainly treated by antipsychotic DRD2 antagonists (Seeman et al., 1976). It is recognized that DRD2 signal through two different pathways: a "traditional" cAMP protein kinase A and phospholipase C pathway (Trantham-Davidson et al., 2004), and a more recently discovered cAMP-independent pathway in which $\beta$-arrestin 2 binds PP2A and Akt, activating GSK3 (Beaulieu et al., 2004, 2005). AKT1 thus regulates G-protein-independent signaling of DRD2 and is involved in DRD2 desensitization and internalization (Oda et al., 2015; Li et al., 2016). Polymorphisms in AKT1 have been associated with SZ (Ikeda et al., 2004; Norton et al., 2007; Chow et al., 2016), psychosis risk in SZ (van Winkel et al., 2011), psychotic responses to cannabis (Di Forti et al., 2012; Morgan et al., 2016), working-memory brain activations, and cortical and striatal volumes (Tan et al., 2008, 2012a,b; Blokland 

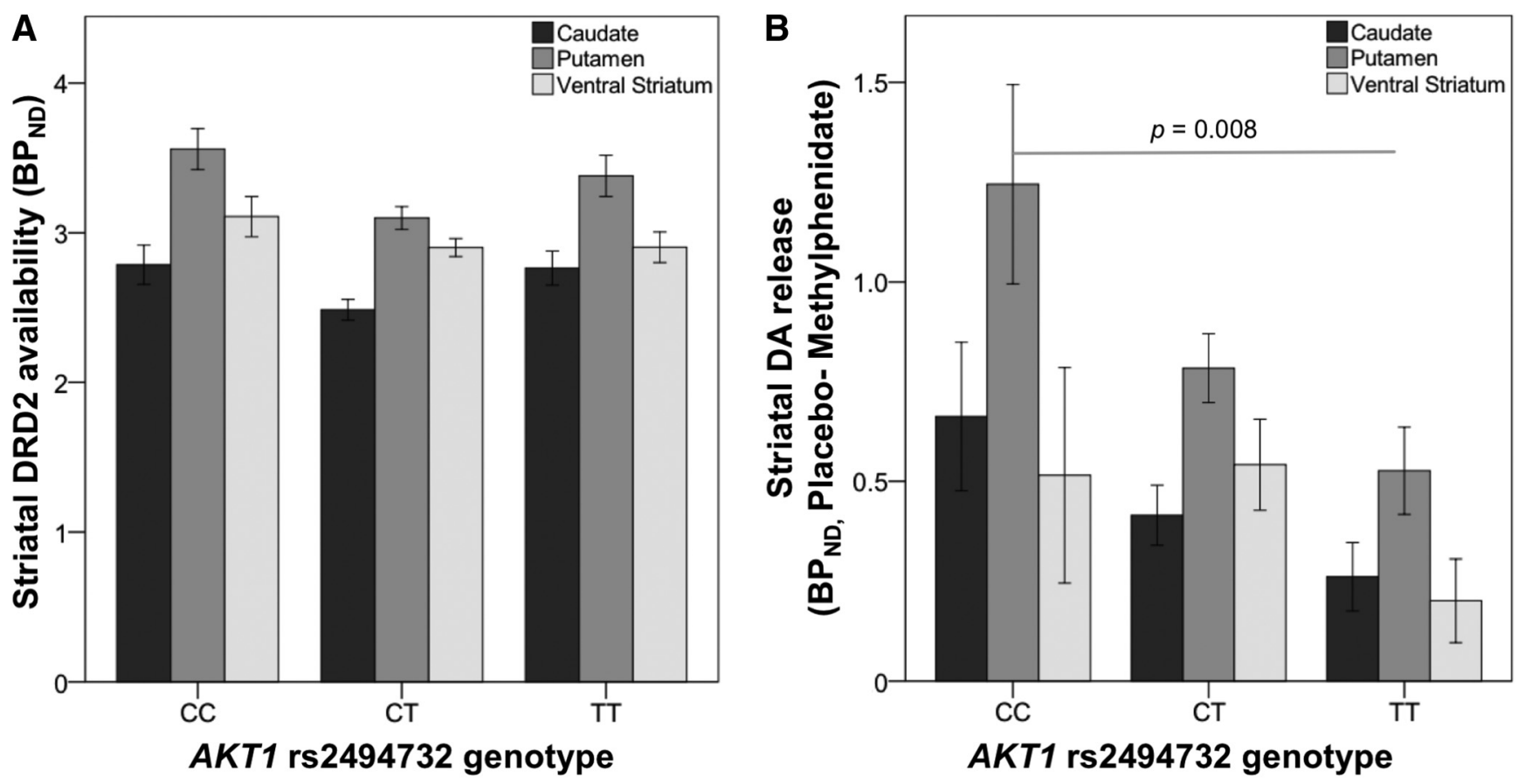

Figure 4. $\boldsymbol{A}, A K T 1$ rs 2494732 genotype had a trend-wise effect on baseline DRD2 in putamen ( $p=0.088$; corrected for age, gender, and ethnicity), but there were no significant effects for the caudate or VS. $\boldsymbol{B}, A K T 1 \mathrm{rs} 2494732$ genotype modulated MP-induced DA release in the putamen only ( $p=0.008)$, corrected for age, gender, and ethnicity. CC showed an enhanced DA response to MP than CT ( $p=0.031)$ and TT $(p=0.003)$. Error bars depict SEM.

et al., 2017). Our study is the first to find that a genetic variant in $A K T 1$ influences striatal DRD2 availability that might reflect Akt's role in DRD2 internalization and membrane availability.

Reports on the genetic variations that explain individual differences in DRD2 expression in the healthy human brain have mostly focused on the ankyrin repeat and kinase domain containing 1 gene (ANKK1) variant rs1800497 (i.e., Taq1A polymorphism; Pohjalainen et al., 1998; Jönsson et al., 1999; Hirvonen et al., 2009; Savitz et al., 2013b; Eisenstein et al., 2016). Overall, these studies have reported lower striatal DRD2 availability for carriers of the minor allele (Lys713) relative to major allele homozygotes (for review, see Gluskin and Mickey, 2016). Brain imaging studies on the DRD2 gene and striatal DRD2 availability have reported associations with SNP rs1079597 (Jönsson et al., 1999; but see Laruelle et al., 1998), with rs6277 and rs1799732 (Gluskin and Mickey, 2016), and with rs 1076560 (Bertolino et al., 2010). We also reported an association between a VNTR polymorphism in the period circadian clock 2 gene PER2 and striatal DRD2 availability (Shumay et al., 2012).

\section{Association between AKT1 VNTR and MP-induced DA release in the striatum}

Our study also revealed that the AKT1 VNTR was associated with $\mathrm{MP}$-induced DA release in the VS. Despite lower DRD2 in AKT1 genotype group $\mathrm{HH}<\mathrm{HL}<\mathrm{LL}$, MP-induced DA release (i.e., $\left[{ }^{11} \mathrm{C}\right]$ raclopride $\mathrm{BP}_{\mathrm{ND}}$ [placebo-MP]) shows the opposite effect of enhanced release in AKT1 genotype groups $\mathrm{HH}>\mathrm{HL}>\mathrm{LL}$. SPM analyses did not meet cluster-correction criterion at $p_{\mathrm{FWE}}<$ 0.05 . However, exploratory results at a liberal threshold of $p<$ 0.05 uncorrected showed activated clusters for $\mathrm{HH}>\mathrm{HL}>\mathrm{LL}$ covering the caudate and anterior putamen, but not for the reverse contrast $\mathrm{HH}<\mathrm{HL}<\mathrm{LL}$, which was in line with the ROI analyses. Most imaging studies in healthy controls on the role of genes on striatal DA release have measured responses to a pain stressor and reported associations with DRD2 rs4274224 (Peciña et al., 2013); serotonin 5HT2C gene (HTR2C) rs6318, Cys23Ser (Mickey et al., 2012); mu opioid receptor gene (OPRM1), rs1799971, A118G (Peciña et al., 2015); leptin gene (LEP) rs12706832 (Burghardt et al., 2012); and in females only, with oxytocin gene (OXT) rs4813625 (Love et al., 2012). The COMT Val158Met variant was also associated with DA release in the prefrontal cortex after a psychosocial stressor (Hernaus et al., 2013). Additionally, studies on gambling-induced DA release have reported an association with DRD3 rs6280 (Savitz et al., 2013a), and with the TaqIA polymorphism (Joutsa et al., 2014). On the other hand, the COMT Val158Met variant was not associated with amphetamineinduced DA release in the prefrontal cortex (Narendran et al., 2016).

Thus, to our knowledge, this is the first study that reports on a gene variant that influences stimulant-induced DA release in the healthy human brain. DA stimulation leads to dephosphorylation of Akt and activation of GSK-3-mediated G-protein-independent signaling. $A K T 1^{-/-}$mice show enhanced responses to amphetamine and ketamine (Emamian et al., 2004; Featherstone et al., 2013), consistent with the belief that depressed Akt function may cause a DA supersensitive state (Oda et al., 2015). The AKT1 VNTR may therefore serve as a biomarker for diseases with disrupted DA signaling, including SZ (Laruelle et al., 1996; Abi-Dargham et al., 1998; Kegeles et al., 2010) and SUD (e.g., in cannabis and cocaine abusers: Volkow et al., 2014a,b; van de Giessen et al., 2017).

The $\mathrm{HH}$ allele, which showed enhanced DA release in VS may serve as a risk allele for SZ and psychoses. Similarly, the C allele of AKT1 SNP rs2494732, which has been associated with SZ (van Winkel et al., 2011; Di Forti et al., 2012), and with cannabisinduced psychosis, compared with TT (Morgan et al., 2016), showed enhanced DA responses to MP (Morgan et al., 2016, Fig. $3 B$ ). Since large DA increases in the striatum are associated with psychosis (Lieberman et al., 1990), the enhanced striatal DA reactivity of $\mathrm{C}$ allele carriers could explain these associations (Di Forti et al., 2012; Morgan et al., 2016). The novel VNTR, how- 
ever, is not in strong LD with rs2494732, and it remains to be explored whether it shows any involvement in SZ and druginduced psychosis.

\section{New VNTR polymorphism in the human $A K T 1$ gene}

The new AKT1 VNTR is not imputable from other markers because it resides outside $A K T 1$ haplotype blocks (HapMap), and is not in strong LD with AKT1 SNPs. The VNTR showed stronger effects on DRD2 than SNP rs2494732, suggesting that it might be a more sensitive marker of striatal dopaminergic signaling. However, future studies are necessary to examine the effects of the novel VNTR in animal models.

The AKT1 gene has high GC content over the entire gene body (the CG density track; Fig. 2, blue arrow), making it amenable to DNA methylation, which impacts gene transcription. Evolutionary analyses of CpG-rich regions (Cohen et al., 2011) showed that enrichment in GC content of $A K T 1$ are evolutionally recent and that one of the Weizmann evolutionary CpG islands (CGI: 3.1) encompasses the VNTR under study. The AKT1 VNTR alters the number of potential DNA methylation sites since each repeated period contains four $\mathrm{CpG}$ sites. Another epigenetic mechanism is nucleosome positioning (Kaplan et al., 2009; Tillo and Hughes, 2009; Levo and Segal, 2014) and the AKT1 VNTR localizes within the nucleosome exclusion region, featuring the highest nucleosome exclusion score within the AKT1 boundaries. This suggests that the polymorphic sequence has open chromatin structure, further strengthening the notion that the VNTR region might contain regulatory elements. The VNTR may therefore modulate the epigenetic potential of $A K T 1$, and, given its proximity to exon 3 , its length may affect splicing fidelity.

\section{Study limitations}

Our study had at least four limitations. First, our sample size was of mixed ethnicity and, despite correcting for ethnicity, effects may be partially due to genetic admixture. Future studies investigating the effect of $A K T 1$ on DRD2 and on DA release should control for population stratification, especially since we found an effect of ethnicity of the AKT1 VNTR. Second, while the AKT1 SNP rs2494732 has been associated with psychosis and SZ (van Winkel et al., 2011; Di Forti et al., 2012; Morgan et al., 2016) and was hence relevant to our PET DA outcome measures, the role of the novel AKT1 VNTR in Akt, in DRD2 protein expression, in SZ, or in psychosis remains to be determined. In addition, the current study was limited to two markers on the $A K T 1$ gene and future studies should investigate other $A K T 1$ markers, including $A K T 1$ rs1130233, which has been associated with working-memory processing (Tan et al., 2012a). Future studies might also study interactions of genetic variants that have been associated with DRD2 or DA release, such as Taq1A, Taq1B, and DRD2 SNPs rs1079597, rs1076560, rs6277, rs1799732, rs12364283, rs2283265 (Zhang et al., 2007; Bertolino et al., 2009a,b; Gluskin and Mickey, 2016). Third, $\left[{ }^{11} \mathrm{C}\right]$ raclopride binds to both $\mathrm{D} 2$ and $\mathrm{D} 3$ receptors and while in dorsal striatum its binding reflects mostly D2, since D3 receptors are very low. In VS the levels are similar and thus we cannot differentiate the relative contribution of $\mathrm{D} 2$ versus $\mathrm{D} 3$ on the association between $A K T 1$ and DA release in VS. Future studies with higher affinity DRD2 tracers (e.g., $\left[{ }^{18} \mathrm{~F}\right]$ fallypride) are needed to test whether $A K T 1$ modulates DRD2 availability in extrastriatal regions. Last, MRI images were not available for all subjects, which limited our capacity to coregister images and determine striatal ROIs. However, we and others have shown that MRI coregistration does not improve quantification of $\left[{ }^{11} \mathrm{C}\right]$ raclopride binding (Wang et al., 1997; Kuhn et al., 2014). This might explain why the
ROI findings were stronger than the voxelwise statistics, which did not reach significance at $p_{\mathrm{FWE}}$ for the effects of $A K T 1$ on baseline DRD2 availability and MP-induced DA release, but only showed significance at a very liberal threshold.

In sum, our findings confirm an involvement of $A K T 1$ in regulating dopaminergic striatal signaling both as it relates to DRD2 availability and stimulant-induced DA release.

\section{References}

Abi-Dargham A, Gil R, Krystal J, Baldwin RM, Seibyl JP, Bowers M, van Dyck CH, Charney DS, Innis RB, Laruelle M (1998) Increased striatal dopamine transmission in schizophrenia: confirmation in a second cohort. Am J Psychiatry 155:761-767. Medline

Arguello PA, Gogos JA (2008) A signaling pathway AKTing up in schizophrenia. J Clin Invest 118:2018-2021. CrossRef Medline

Barrett JC, Fry B, Maller J, Daly MJ (2005) Haploview: analysis and visualization of LD and haplotype maps. Bioinformatics 21:263-265. CrossRef Medline

Beaulieu JM, Sotnikova TD, Yao WD, Kockeritz L, Woodgett JR, Gainetdinov RR, Caron MG (2004) Lithium antagonizes dopamine-dependent behaviors mediated by an AKT/glycogen synthase kinase 3 signaling cascade. Proc Natl Acad Sci U S A 101:5099-5104. CrossRef Medline

Beaulieu JM, Sotnikova TD, Marion S, Lefkowitz RJ, Gainetdinov RR, Caron MG (2005) An Akt/beta-arrestin 2/PP2A signaling complex mediates dopaminergic neurotransmission and behavior. Cell 122:261-273. CrossRef Medline

Beaulieu JM, Gainetdinov RR, Caron MG (2007) The Akt-GSK-3 signaling cascade in the actions of dopamine. Trends Pharmacol Sci 28:166-172. CrossRef Medline

Bertolino A, Fazio L, Di Giorgio A, Blasi G, Romano R, Taurisano P, Caforio G, Sinibaldi L, Ursini G, Popolizio T, Tirotta E, Papp A, Dallapiccola B, Borrelli E, Sadee W (2009a) Genetically determined interaction between the dopamine transporter and the $\mathrm{D} 2$ receptor on prefronto-striatal activity and volume in humans. J Neurosci 29:1224-1234. CrossRef Medline

Bertolino A, Fazio L, Caforio G, Blasi G, Rampino A, Romano R, Di Giorgio A, Taurisano P, Papp A, Pinsonneault J, Wang D, Nardini M, Popolizio T, Sadee W (2009b) Functional variants of the dopamine receptor D2 gene modulate prefronto-striatal phenotypes in schizophrenia. Brain 132:417425. CrossRef Medline

Bertolino A, Taurisano P, Pisciotta NM, Blasi G, Fazio L, Romano R, Gelao B, Lo Bianco L, Lozupone M, Di Giorgio A, Caforio G, Sambataro F, NiccoliAsabella A, Papp A, Ursini G, Sinibaldi L, Popolizio T, Sadee W, Rubini G (2010) Genetically determined measures of striatal D2 signaling predict prefrontal activity during working memory performance. PloS One 5:e9348. CrossRef Medline

Blasi G, Napolitano F, Ursini G, Taurisano P, Romano R, Caforio G, Fazio L, Gelao B, Di Giorgio A, Iacovelli L, Sinibaldi L, Popolizio T, Usiello A, Bertolino A (2011) DRD2/AKT1 interaction on D2 c-AMP independent signaling, attentional processing, and response to olanzapine treatment in schizophrenia. Proc Natl Acad Sci U S A 108:1158-1163. CrossRef Medline

Blokland GA, Wallace AK, Hansell NK, Thompson PM, Hickie IB, Montgomery GW, Martin NG, McMahon KL, de Zubicaray GI, Wright MJ (2017) Genome-wide association study of working memory brain activation. Int J Psychophysiol 155:98-111. CrossRef Medline

Brinkmann B, Klintschar M, Neuhuber F, Hühne J, Rolf B (1998) Mutation rate in human microsatellites: influence of the structure and length of the tandem repeat. Am J Hum Genet 62:1408-1415. CrossRef Medline

Burghardt PR, Love TM, Stohler CS, Hodgkinson C, Shen PH, Enoch MA, Goldman D, Zubieta JK (2012) Leptin regulates dopamine responses to sustained stress in humans. J Neurosci 32:15369-15376. CrossRef Medline

Bychkov E, Ahmed MR, Dalby KN, Gurevich EV (2007) Dopamine depletion and subsequent treatment with L-DOPA, but not the long-lived dopamine agonist pergolide, enhances activity of the Akt pathway in the rat striatum. J Neurochem 102:699-711. CrossRef Medline

Chow TJ, Tee SF, Yong HS, Tang PY (2016) Genetic association of TCF4 and AKT1 gene variants with the age at onset of schizophrenia. Neuropsychobiology 73:233-240. CrossRef Medline

Cohen NM, Kenigsberg E, Tanay A (2011) Primate CpG islands are maintained by heterogeneous evolutionary regimes involving minimal selection. Cell 145:773-786. CrossRef Medline 
Di Forti M, Iyegbe C, Sallis H, Kolliakou A, Falcone MA, Paparelli A, Sirianni M, La Cascia C, Stilo SA, Marques TR, Handley R, Mondelli V, Dazzan P, Pariante C, David AS, Morgan C, Powell J, Murray RM (2012) Confirmation that the AKT1 (rs2494732) genotype influences the risk of psychosis in cannabis users. Biol Psychiatry 72:811-816. CrossRef Medline

Eisenstein SA, Bogdan R, Love-Gregory L, Corral-FríasNS, Koller JM, Black KJ, Moerlein SM, Perlmutter JS, Barch DM, Hershey T (2016) Prediction of striatal D2 receptor binding by DRD2/ANKK1 TaqIA allele status. Synapse 70:418-431. CrossRef Medline

Emamian ES, Hall D, Birnbaum MJ, Karayiorgou M, Gogos JA (2004) Convergent evidence for impaired AKT1-GSK3beta signaling in schizophrenia. Nat Genet 36:131-137. CrossRef Medline

Featherstone RE, M Tatard-Leitman V, Suh JD, Lin R, Lucki I, Siegel SJ (2013) Electrophysiological and behavioral responses to ketamine in mice with reduced Akt1 expression. Psychopharmacology 227:639-649. CrossRef Medline

Gainetdinov RR, Premont RT, Bohn LM, Lefkowitz RJ, Caron MG (2004) Desensitization of $\mathrm{G}$ protein-coupled receptors and neuronal functions. Annu Rev Neurosci 27:107-144. CrossRef Medline

Gluskin BS, Mickey BJ (2016) Genetic variation and dopamine D2 receptor availability: a systematic review and meta-analysis of human in vivo molecular imaging studies. Transl Psychiatry 6:e747. CrossRef Medline

Gulcher J (2012) Microsatellite markers for linkage and association studies. Cold Spring Harb Protoc 2012:425-432. CrossRef Medline

Hall D, Gogos JA, Karayiorgou M (2004) The contribution of three strong candidate schizophrenia susceptibility genes in demographically distinct populations. Genes Brain Behav 3:240-248. CrossRef Medline

Hernaus D, Collip D, Lataster J, Ceccarini J, Kenis G, Booij L, Pruessner J, Van Laere K, van Winkel R, van Os J, Myin-Germeys I (2013) COMT Val158Met genotype selectively alters prefrontal [18F]fallypride displacement and subjective feelings of stress in response to a psychosocial stress challenge. PloS One 8:e65662. CrossRef Medline

Hirvonen M, Laakso A, Någren K, Rinne JO, Pohjalainen T, Hietala J (2004) C957T polymorphism of the dopamine D2 receptor (DRD2) gene affects striatal DRD2 availability in vivo. Mol Psychiatry 9:1060-1061. CrossRef Medline

Hirvonen MM, Laakso A, Någren K, Rinne JO, Pohjalainen T, Hietala J (2009) C957T polymorphism of dopamine D2 receptor gene affects striatal DRD2 in vivo availability by changing the receptor affinity. Synapse 63:907-912. CrossRef Medline

Hou H, Wang C, Jia S, Hu S, Tian M (2014) Brain dopaminergic system changes in drug addiction: a review of positron emission tomography findings. Neurosci Bull 30:765-776. CrossRef Medline

Ikeda M, Iwata N, Suzuki T, Kitajima T, Yamanouchi Y, Kinoshita Y, Inada T, Ozaki N (2004) Association of AKT1 with schizophrenia confirmed in a Japanese population. Biol Psychiatry 56:698-700. CrossRef Medline

Ishibashi K, Ishii K, Oda K, Kawasaki K, Mizusawa H, Ishiwata K (2009) Regional analysis of age-related decline in dopamine transporters and dopamine D2-like receptors in human striatum. Synapse 63:282-290. CrossRef Medline

Jönsson EG, Nöthen MM, GrünhageF, Farde L, Nakashima Y, Propping P, Sedvall GC (1999) Polymorphisms in the dopamine D2 receptor gene and their relationships to striatal dopamine receptor density of healthy volunteers. Mol Psychiatry 4:290-296. CrossRef Medline

Joutsa J, Hirvonen MM, Arponen E, Hietala J, Kaasinen V (2014) DRD2related TaqIA genotype is associated with dopamine release during a gambling task. J Addict Med 8:294-295. CrossRef Medline

Kaplan N, Moore IK, Fondufe-Mittendorf Y, Gossett AJ, Tillo D, Field Y, LeProust EM, Hughes TR, Lieb JD, Widom J, Segal E (2009) The DNAencoded nucleosome organization of a eukaryotic genome. Nature 458: 362-366. CrossRef Medline

Kegeles LS, Abi-Dargham A, Frankle WG, Gil R, Cooper TB, Slifstein M, Hwang DR, Huang Y, Haber SN, Laruelle M (2010) Increased synaptic dopamine function in associative regions of the striatum in schizophrenia. Arch Gen psychiatry 67:231-239. CrossRef Medline

Kim JH, Son YD, Kim HK, Lee SY, Cho SE, Kim YB, Cho ZH (2011) Effects of age on dopamine D2 receptor availability in striatal subdivisions: a high-resolution positron emission tomography study. Eur Neuropsychopharmacol 21:885-891. CrossRef Medline

Kuhn FP, Warnock GI, Burger C, Ledermann K, Martin-Soelch C, Buck A (2014) Comparison of PET template-based and MRI-based image pro- cessing in the quantitative analysis of C11-raclopride PET. EJNMMI research 4:7. CrossRef Medline

Laruelle M, Abi-Dargham A, van Dyck CH, Gil R, D'Souza CD, Erdos J, McCance E, Rosenblatt W, Fingado C, Zoghbi SS, Baldwin RM, Seibyl JP, Krystal JH, Charney DS, Innis RB (1996) Single photon emission computerized tomography imaging of amphetamine-induced dopamine release in drug-free schizophrenic subjects. Proc Natl Acad Sci U S A 93: 9235-9240. CrossRef Medline

Laruelle M, Gelernter J, Innis RB (1998) D2 receptors binding potential is not affected by Taq1 polymorphism at the D2 receptor gene. Mol Psychiatry 3:261-265. CrossRef Medline

Legendre M, Verstrepen KJ (2008) Using the SERV applet to detect tandem repeats in DNA sequences and to predict their variability. CSH Protoc 2008:pdb.ip50. CrossRef Medline

Levo M, Segal E (2014) In pursuit of design principles of regulatory sequences. Nat Rev Genet 15:453-468. CrossRef Medline

Li YC, Yang SS, Gao WJ (2016) Disruption of Akt signaling decreases dopamine sensitivity in modulation of inhibitory synaptic transmission in rat prefrontal cortex. Neuropharmacology 108:403-414. CrossRef Medline

Lieberman JA, Kinon BJ, Loebel AD (1990) Dopaminergic mechanisms in idiopathic and drug-induced psychoses. Schizophr Bull 16:97-110. CrossRef Medline

Logan J, Fowler JS, Volkow ND, Wolf AP, Dewey SL, Schlyer DJ, MacGregor RR, Hitzemann R, Bendriem B, Gatley SJ (1990) Graphical analysis of reversible radioligand binding from time-activity measurements applied to [N-11C-methyl]-(-)-cocaine PET studies in human subjects. J Cereb Blood Flow Metab 10:740-747. CrossRef Medline

Logan J, Fowler JS, Volkow ND, Wang GJ, Ding YS, Alexoff DL (1996) Distribution volume ratios without blood sampling from graphical analysis of PET data. J Cereb Blood Flow Metab 16:834-840. Medline

Love TM, Enoch MA, Hodgkinson CA, Peciña M, Mickey B, Koeppe RA, Stohler CS, Goldman D, Zubieta JK (2012) Oxytocin gene polymorphisms influence human dopaminergic function in a sex-dependent manner. Biol Psychiatry 72:198-206. CrossRef Medline

MacDonald JR, Ziman R, Yuen RK, Feuk L, Scherer SW (2014) The Database of Genomic Variants: a curated collection of structural variation in the human genome. Nucleic Acids Res 42:D986-D992. CrossRef Medline

Mickey BJ, Sanford BJ, Love TM, Shen PH, Hodgkinson CA, Stohler CS, Goldman D, Zubieta JK (2012) Striatal dopamine release and genetic variation of the serotonin $2 \mathrm{C}$ receptor in humans. J Neurosci 32:93449350. CrossRef Medline

Morgan CJ, Freeman TP, Powell J, Curran HV (2016) AKT1 genotype moderates the acute psychotomimetic effects of naturalistically smoked cannabis in young cannabis smokers. Transl Psychiatry 6:e738. CrossRef Medline

Narendran R, Tumuluru D, May MA, Chowdari KV, Himes ML, Fasenmyer K, Frankle WG, Nimgaonkar VL (2016) Cortical dopamine transmission as measured with the [11C]FLB 457-amphetamine PET imaging paradigm is not influenced by COMT genotype. PloS One 11:e0157867. CrossRef Medline

Norton N, Williams HJ, Dwyer S, Carroll L, Peirce T, Moskvina V, Segurado R, Nikolov I, Williams NM, Ikeda M, Iwata N, Owen MJ, O’Donovan MC (2007) Association analysis of AKT1 and schizophrenia in a UK case control sample. Schizophr Res 93:58-65. CrossRef Medline

Oda Y, Kanahara N, Iyo M (2015) Alterations of dopamine D2 receptors and related receptor-interacting proteins in schizophrenia: the pivotal position of dopamine supersensitivity psychosis in treatment-resistant schizophrenia. Int J Mol Sci 16:30144-30163. CrossRef Medline

Ohi K, Hashimoto R, Yasuda Y, Fukumoto M, Nemoto K, Ohnishi T, Yamamori H, Takahashi H, Iike N, Kamino K, Yoshida T, Azechi M, Ikezawa K, Tanimukai H, Tagami S, Morihara T, Okochi M, Tanaka T, Kudo T, Iwase M, et al. (2013) The AKT1 gene is associated with attention and brain morphology in schizophrenia. World J Biol Psychiatry 14:100-113. CrossRef Medline

Pan JQ, Lewis MC, Ketterman JK, Clore EL, Riley M, Richards KR, BerryScott E, Liu X, Wagner FF, Holson EB, Neve RL, Biechele TL, Moon RT, Scolnick EM, Petryshen TL, Haggarty SJ (2011) AKT kinase activity is required for lithium to modulate mood-related behaviors in mice. Neuropsychopharmacology 36:1397-1411. CrossRef Medline

Peciña M, Mickey BJ, Love T, Wang H, Langenecker SA, Hodgkinson C, Shen PH, Villafuerte S, Hsu D, Weisenbach SL, Stohler CS, Goldman D, Zubieta JK (2013) DRD2 polymorphisms modulate reward and emotion 
processing, dopamine neurotransmission and openness to experience. Cortex 49:877-890. CrossRef Medline

Peciña M, Love T, Stohler CS, Goldman D, Zubieta JK (2015) Effects of the mu opioid receptor polymorphism (OPRM1 A118G) on pain regulation, placebo effects and associated personality trait measures. Neuropsychopharmacology 40:957-965. CrossRef Medline

Pohjalainen T, Rinne JO, Någren K, Lehikoinen P, Anttila K, Syvälahti EK, Hietala J (1998) The A1 allele of the human D2 dopamine receptor gene predicts low D2 receptor availability in healthy volunteers. Mol Psychiatry 3:256-260. CrossRef Medline

Savitz J, Hodgkinson CA, Martin-Soelch C, Shen PH, Szczepanik J, Nugent A, Herscovitch P, Grace AA, Goldman D, Drevets WC (2013a) The functional DRD3 Ser9Gly polymorphism (rs6280) is pleiotropic, affecting reward as well as movement. PloS One 8:e54108. CrossRef Medline

Savitz J, Hodgkinson CA, Martin-Soelch C, Shen PH, Szczepanik J, Nugent AC, Herscovitch P, Grace AA, Goldman D, Drevets WC (2013b) DRD2/ ANKK1 Taq1A polymorphism (rs1800497) has opposing effects on D2/3 receptor binding in healthy controls and patients with major depressive disorder. Int J Neuropsychopharmacol 16:2095-2101. CrossRef Medline

Seeman P, Lee T, Chau-Wong M, Wong K (1976) Antipsychotic drug doses and neuroleptic/dopamine receptors. Nature 261:717-719. CrossRef Medline

Shumay E, Fowler JS, Wang GJ, Logan J, Alia-Klein N, Goldstein RZ, Maloney T, Wong C, Volkow ND (2012) Repeat variation in the human PER2 gene as a new genetic marker associated with cocaine addiction and brain dopamine D2 receptor availability. Transl Psychiatry 2:e86. CrossRef Medline

Smith SM, Nichols TE (2009) Threshold-free cluster enhancement: addressing problems of smoothing, threshold dependence and localisation in cluster inference. Neuroimage 44:83-98. CrossRef Medline

Tan HY, Nicodemus KK, Chen Q, Li Z, Brooke JK, Honea R, Kolachana BS, Straub RE, Meyer-Lindenberg A, Sei Y, Mattay VS, Callicott JH, Weinberger DR (2008) Genetic variation in AKT1 is linked to dopamineassociated prefrontal cortical structure and function in humans. J Clin Invest 118:2200-2208. CrossRef Medline

Tan HY, Chen AG, Kolachana B, Apud JA, Mattay VS, Callicott JH, Chen Q, Weinberger DR (2012a) Effective connectivity of AKT1-mediated dopaminergic working memory networks and pharmacogenetics of antidopaminergic treatment. Brain 135:1436-1445. CrossRef Medline

Tan HY, Chen AG, Chen Q, Browne LB, Verchinski B, Kolachana B, Zhang F, Apud J, Callicott JH, Mattay VS, Weinberger DR (2012b) Epistatic interactions of AKT1 on human medial temporal lobe biology and pharmacogenetic implications. Mol Psychiatry 17:1007-1016. CrossRef Medline

Tillo D, Hughes TR (2009) G+C content dominates intrinsic nucleosome occupancy. BMC Bioinformatics 10:442. CrossRef Medline

Trantham-Davidson H, Neely LC, Lavin A, Seamans JK (2004) Mechanisms underlying differential D1 versus D2 dopamine receptor regulation of inhibition in prefrontal cortex. J Neurosci 24:10652-10659. CrossRef Medline

van de Giessen E, Weinstein JJ, Cassidy CM, Haney M, Dong Z, Ghazzaoui R, Ojeil N, Kegeles LS, Xu X, Vadhan NP, Volkow ND, Slifstein M, AbiDargham A (2017) Deficits in striatal dopamine release in cannabis dependence. Mol Psychiatry 22:68-75. CrossRef Medline

van Winkel R, van Beveren NJ, Simons C, Simons C (2011) AKT1 moderation of cannabis-induced cognitive alterations in psychotic disorder. Neuropsychopharmacology 36:2529-2537. CrossRef Medline
Volkow ND, Wang GJ, Fowler JS, Logan J, Schlyer D, Hitzemann R, Lieberman J, Angrist B, Pappas N, MacGregor R (1994) Imaging endogenous dopamine competition with [11C] raclopride in the human brain. Synapse 16:255-262. CrossRef Medline

Volkow ND, Logan J, Fowler JS, Wang GJ, Gur RC, Wong C, Felder C, Gatley SJ, Ding YS, Hitzemann R, Pappas N (2000) Association between agerelated decline in brain dopamine activity and impairment in frontal and cingulate metabolism. Am J Psychiatry 157:75-80. Medline

Volkow ND, Wang GJ, Fowler JS, Tomasi D (2012a) Addiction circuitry in the human brain. Annu Rev Pharmacol Toxicol 52:321-336. CrossRef Medline

Volkow ND, Wang GJ, Tomasi D, Kollins SH, Wigal TL, Newcorn JH, Telang FW, Fowler JS, Logan J, Wong CT, Swanson JM (2012b) Methylphenidateelicited dopamine increases in ventral striatum are associated with long-term symptom improvement in adults with attention deficit hyperactivity disorder. J Neurosci 32:841-849. CrossRef Medline

Volkow ND, Wang GJ, Telang F, Fowler JS, Alexoff D, Logan J, Jayne M, Wong C, Tomasi D (2014a) Decreased dopamine brain reactivity in marijuana abusers is associated with negative emotionality and addiction severity. Proc Natl Acad Sci U S A 111:E3149-E3156. CrossRef Medline

Volkow ND, Tomasi D, Wang GJ, Logan J, Alexoff DL, Jayne M, Fowler JS, Wong C, Yin P, Du C (2014b) Stimulant-induced dopamine increases are markedly blunted in active cocaine abusers. Mol Psychiatry 19:10371043. CrossRef Medline

Wang GJ, Volkow ND, Fowler JS, Logan J, Abumrad NN, Hitzemann RJ, Pappas NS, Pascani K (1997) Dopamine D2 receptor availability in opiate-dependent subjects before and after naloxone-precipitated withdrawal. Neuropsychopharmacology 16:174-182. CrossRef Medline

Wang GJ, Volkow ND, Fowler JS, Logan J, Pappas NR, Wong CT, Hitzemann RJ, Netusil N (1999) Reproducibility of repeated measures of endogenous dopamine competition with [11C]raclopride in the human brain in response to methylphenidate. J Nucl Med 40:1285-1291. Medline

Wang GJ, Smith L, Volkow ND, Telang F, Logan J, Tomasi D, Wong CT, Hoffman W, Jayne M, Alia-Klein N, Thanos P, Fowler JS (2012) Decreased dopamine activity predicts relapse in methamphetamine abusers. Mol Psychiatry 17:918-925. CrossRef Medline

Weber JL, Wong C (1993) Mutation of human short tandem repeats. Hum Mol Genet 2:1123-1128. CrossRef Medline

Weinstein JJ, Chohan MO, Slifstein M, Kegeles LS, Moore H, Abi-Dargham A (2016) Pathway-specific dopamine abnormalities in schizophrenia. Biol Psychiatry 81:31-42.

Winkler AM, Ridgway GR, Webster MA, Smith SM, Nichols TE (2014) Permutation inference for the general linear model. Neuroimage 92:381397. CrossRef Medline

Wong AH, Buckle CE, Van Tol HH (2000) Polymorphisms in dopamine receptors: what do they tell us? Eur J Pharmacol 410:183-203. CrossRef Medline

Zhang Y, Bertolino A, Fazio L, Blasi G, Rampino A, Romano R, Lee ML, Xiao T, Papp A, Wang D, Sadée W (2007) Polymorphisms in human dopamine D2 receptor gene affect gene expression, splicing, and neuronal activity during working memory. Proc Natl Acad Sci U S A 104:2055220557. CrossRef Medline

Zheng H, Wang X, Tang Z, Zheng W, Li Z (2013) The PI3K/Akt and ERK1/2 signaling pathways mediate the erythropoietin-modulated calcium influx in kainic acid-induced epilepsy. Neuroreport 24:335-341. CrossRef Medline 